\title{
Pulmonary Alveolar Type II Epithelial Cells Synthesize and Secrete Proteins of the Classical and Alternative Complement Pathways
}

Robert C. Strunk, Denise M. Eidlen, and Robert J. Mason

Departments of Pediatrics and Medicine, National Jewish Center for Immunology and Respiratory Medicine, Denver, Colorado 80206, and the University of Colorado School of Medicine, Denver, Colorado 80206

\begin{abstract}
The serum complement system is a major mediator of inflammation reactions. Two of the complement proteins, the third (C3) and fifth (C5) components, are precursors of potent phlogistic molecules, C3a and C5a. C5a has potent chemotactic activity and plays an active role in pulmonary inflammation. We present evidence suggesting that several complement proteins, including C5, are synthesized locally in the lung in alveolar type II epithelial cells. Lung tissue from normal mice synthesized and secreted $C 5$ protein similar to the $C 5$ protein in mouse serum, whereas lung tissue from C5-deficient mice did not. Lung tissues from both normal and C5-deficient mice synthesized C3. Rat lung tissue synthesized and secreted C5, as well as $\mathrm{C2}, \mathrm{C4}, \mathrm{C3}$, and factor B. Cultures of type II cells (95\% type II cells, 5\% macrophages) regularly synthesized all these proteins. In contrast, cultures of macrophages alone synthesized large amounts of $\mathrm{C} 2$ and factor $\mathrm{B}$, and in some experiments $\mathrm{C} 3$ and $\mathrm{C4}$, but never $\mathrm{C} 5$. The $\mathrm{C5}$ synthesized by the rat cells was slightly larger than serum $\mathrm{C5}(200 \mathrm{kD}$ compared with $180 \mathrm{kD}$ ) and was not processed to the two-chain molecule seen in serum. Rat lung tissue and purified type II cells contained C5 mRNA with the same molecular mass as the C5 mRNA in rat liver and in mouse lung and liver. Human type II cells also synthesized C5, as well as C2, C4, C3, and factor B. Human pulmonary macrophages synthesized only $\mathrm{C} 2$, factor $\mathrm{B}$, and, in some experiments, C3. Synthesis of complement proteins in cells that line the alveolar wall may provide a local source of these proteins for inflammatory responses in the lung. Local synthesis of complement proteins could be regulated independently of the synthesis in the liver.
\end{abstract}

\section{Introduction}

The complement system, a set of 20 plasma proteins, is an effector of several functions associated with inflammation, immunologic regulation, and cytotoxicity (1). Two of these proteins, the third (C3) and fifth (C5) components, are precursors of potent phlogistic molecules, $\mathrm{C} 3 \mathrm{a}$ and $\mathrm{C} 5 \mathrm{a}$. C5a has potent chemotactic activity (2) and has been implicated in the initiation of pulmonary inflammation in both animals and man. Direct instillation of C5a into the lungs of rabbits results in

Address reprint requests to Dr. Robert C. Strunk, Washington University School of Medicine, Children's Hospital, 400 S. Kingshighway Blvd., St. Louis, MO 63110.

Received for publication 20 July 1987 and in revised form 9 December 1987.

J. Clin. Invest.

(c) The American Society for Clinical Investigation, Inc.

$0021-9738 / 88 / 05 / 1419 / 08 \$ 2.00$

Volume 81, May 1988, 1419-1426 massive influx of neutrophils into the lungs (3). In addition, mice that are congenitally deficient in C5 have markedly decreased and delayed inflammatory responses to a number of stimuli (4-6). Transfusion of plasma from normal mice (containing C5) into the deficient animals before administration of the inflammatory stimulus restores the inflammatory response (5). In addition, activation of C5 in man is associated with leukocyte-mediated pulmonary dysfunction (7).

$\mathrm{C} 5 \mathrm{a}$ can be generated from $\mathrm{C} 5$ by either the classical or the alternative complement activation pathways (1). Although the liver is the major site of synthesis of the complement proteins $(8,9)$, components of both activation pathways are produced locally in lung tissue, $\mathrm{C} 1$ in fibroblasts (10), and C2, C4, C3, and factor $B$ in macrophages (11-13). Kreutzer and coworkers (14) have reported production of hemolytically active C5 in cultures of fetal lung cells and suggested that type II epithelial cells may be a site of $\mathrm{C} 5$ synthesis. The purpose of these studies was to investigate the source of C5 synthesis in lung tissue. We have used purified alveolar type II epithelial cells from humans and rats to study the synthesis of individual complement proteins in vitro. We report that both human and rat alveolar type II epithelial cells synthesize proteins in both the classical and alternative activation pathways, as well as $\mathrm{C} 3$ and $\mathrm{C} 5$. The local production of complement proteins may be important in pulmonary inflammation.

\section{Methods}

\section{Reagents}

Dulbecco's modified minimal essential medium (DMEM) ${ }^{1}$ was purchased from M.A. Bioproducts, Walkersville, MD; DME 80-0072 (without methionine) from Gibco Laboratories, Grand Island, NY; and fetal bovine serum, penicillin, streptomycin, and L-glutamine from Flow Laboratories, McLean, VA. Albumin bovine crystallized, purity: 98\% minimum, was purchased from ICN Nutritional Biochemicals, Cleveland, OH. Pepstatin A was purchased from Sigma Chemical Co., St. Louis, MO. L- $\left[{ }^{35}\right.$ S $]$ Methionine (specific radioactivity, $\sim 1,000$ $\mathrm{Ci} / \mathrm{mmol}$ ), ${ }^{32} \mathrm{P}$-labeled deoxycytidine triphosphate (specific radioactivity $\sim 667 \mathrm{Ci} / \mathrm{mmol}$ ), and $\mathrm{En}^{3} \mathrm{Hance}$ were purchased from New England Nuclear, Boston, MA. Protein standards were purchased from Pharmacia Fine Chemicals, Piscataway, NJ. Formalin-fixed Staphylococcus aureus (Cowan strain 2, IgGsorb) was obtained from The Enzyme Center, Malden, MA. Purified human C5 was kindly provided by Dr. Brian Tack, Scripps Research Institute, La Jolla, CA.

Antisera were obtained as follows. Mouse anti-mouse $\mathrm{C} 5$ was prepared by multiple subcutaneous injections of C5-deficient mice (B10.D2/oSn) with plasma from normal, or C5-sufficient, mice (B10.D2/nSn) mixed 1:1 with CFA, as previously described (15). Anti-human C2 prepared in sheep was obtained from Seward Labs (London, England), IgG fractions of goat anti-human C3, factor B,

1. Abbreviations used in this paper: DMEM, Dulbecco's modified minimal essential medium. 
and C4 from Atlantic Antibodies (Scarborough, ME), and goat antihuman C5 from Miles Scientific Div., Miles Labs Inc. (Naperville, IL). An MAb to human C5 was kindly provided by Dr. Patricia Giclas, National Jewish Center for Immunology and Respiratory Medicine. Since $\mathrm{C} 5$ and $\mathrm{C} 3$ are similar in size and subunit structure and purified preparations of $\mathrm{C} 5$ used for production of antibody can easily be contaminated with $\mathrm{C} 3$, specificity of the antisera for $\mathrm{C} 5$ was confirmed. For mouse C5, all three anti-C5 antisera detected protein in serum of normal, but not $\mathrm{C5}$-deficient, mice. For rat $\mathrm{C5}$, the antisera precipitated a rat serum protein of the size and subunit structure characteristic for serum C5. For human C5, precipitation of labeled C5 from lysate and extracellular medium of HepG2 cells biosynthetically labeled with $\left[{ }^{35} \mathrm{~S}\right]$ methionine was blocked with purified human $\mathrm{C} 5$, whereas the purified $\mathrm{C} 5$ had no effect on the precipitation of $\mathrm{C} 3$ by the goat antihuman C3.

Materials for stimulation of complement synthesis in rat type II cells were obtained as follows. Rat spleen cells were minced and stimulated with $5 \mathrm{mg} / \mathrm{ml}$ Con A for $24 \mathrm{~h}$. Alpha methyl mannoside was added to the supernatants, which were diluted from 1:2.5 to 1:10 with DMEM (containing only penicillin, streptomycin, and L-glutamine) before addition to the type II cells. Medium containing Con A and alpha methyl mannoside, but not exposed to the spleen cells, was used as control. Mouse recombinant gamma IFN was obtained from Dr. Priscilla Campbell at the National Jewish Center for Immunology and Respiratory Medicine and LPS 0111:B4 Westphal extraction from Sigma Chemical Co.

\section{Cells}

Rat type II cells. Type II cells were obtained from specific pathogenfree male Sprague-Dawley rats by a modification of the elastase method described by Dobbs et al. (16). Briefly, after killing, a tracheostomy was performed and the pulmonary vasculature was perfused with HBSS. The lungs were excised and lavaged eight times to remove as many of the alveolar macrophages as possible. The lungs were then instilled via the trachea with a fluorocarbon-albumin emulsion as a phagocytosible article, incubated in a saline waterbath at $37^{\circ} \mathrm{C}$ for $20 \mathrm{~min}$, and lavaged eight additional times to remove any remaining macrophages. EGTA was added for the last two lavages to loosen some of the intercellular junctional complexes, and elastase was then instilled via the airway. After a second incubation at $37^{\circ} \mathrm{C}$ for 20 min, the lungs were removed, minced, and a single cell suspension was obtained by filtration through nylon mesh. The cells were separated on a discontinuous metrizamide density gradient and then plated on tissue culture plastic in $10 \%$ FCS for $24 \mathrm{~h}$ before nonadherent cells were removed by washing. Type II cells were identified by the modified Papanicolaou stain (17), the tannic acid and polychrome stain (18), and alkaline phosphatase staining (19). Quantitation was done with alkaline phosphatase, but is essentially identical to the other proce- dures. These stains are negative for macrophages. The adherent cells were $94 \pm 2 \%$ type II cells (Table I).

Rat type II cells were also prepared after initial adherence of pulmonary macrophages on dishes coated with rat IgG (20). Plates for adherence of the macrophages from the cell suspension were prepared by incubating 35-mm bacteriologic plastic dishes each with $1 \mathrm{ml}$ of rat IgG solution (Sigma Chemical Co.; $500 \mu \mathrm{g} / \mathrm{ml}$ in $50 \mathrm{mM}$ Tris-base, $\mathrm{pH}$ 9.5) for $3 \mathrm{~h}$ at $22^{\circ} \mathrm{C}$, and then washing five times with phosphate-buffered saline and once with DMEM. After incubation of the lung with elastase (20), the cells were filtered through nylon mesh and centrifuged at $130 \mathrm{~g}$ for $8 \mathrm{~min}$ at $4^{\circ} \mathrm{C}$. The cell pellet was resuspended gently at $1.2-1.9 \times 10^{6}$ cells $/ \mathrm{ml}$ in DMEM containing $2 \mathrm{mM}$ L-glutamine, $100 \mathrm{U} / \mathrm{ml}$ penicillin, $100 \mu \mathrm{g} / \mathrm{ml}$ streptomycin, $10 \mu \mathrm{g} / \mathrm{ml}$ gentamicin sulfate, and $2.5 \mu \mathrm{g} / \mathrm{ml}$ amphotericin B without serum. $2 \mathrm{ml}$ of the cell suspension was added to each $35-\mathrm{mm}$ IgG-coated dish and allowed to adhere for $1 \mathrm{~h}$ at $37^{\circ} \mathrm{C}$ and $10 \% \mathrm{CO}_{2}$. The plates were then gently tipped back and forth three times to free loosely adherent type II cells while not detaching adherent macrophages. The unattached cells were supplemented with $10 \%$ fetal bovine serum and transferred to $35-\mathrm{mm}$ tissue culture dishes. Type II cells were allowed to adhere during a 24-h incubation at $37^{\circ} \mathrm{C}$ in $10 \% \mathrm{CO}_{2}$.

The rat type II cells prepared by both the standard elastase method (16) and the alternative (IgG adherence) method (20) had similar capacities to produce complement proteins. Therefore, the results of experiments with these two preparation procedures were combined.

Human type II cells. Type II cells were isolated from resected human lung by the method described by Robinson et al. (21). Specimens were obtained from patients undergoing lobectomy or pneumonectomy for cancer. Pathologists removed the tumor, and a piece of adjacent lung encased in pleura was used for the isolation. Airways of resected lung were cannulated and the lungs lavaged with HBSS and then instilled with pancreatic elastase. After digestion, the lungs were minced and the dissociated cells were isolated by filtration through nylon mesh and then separated on a metrizamide density gradient. The macrophages were removed by adherence to tissue culture plastic for $90 \mathrm{~min}$. The nonadherent type II cells were replated on culture dishes coated with extracellular matrix from bovine endothelial cells (22) and allowed to adhere for $24 \mathrm{~h}$ before the cells were washed. The adherent cells were $89 \pm 4 \%$ type II cells.

Rat pulmonary macrophages. Macrophages were obtained as a byproduct of the rat type II cell preparations in one of two ways. First, bronchoalveolar cells from the initial lavage after excision of the lungs were collected by centrifugation, washed, and resuspended in DMEM without serum for adherence on tissue culture plastic dishes. In most experiments, $1 \times 10^{6}$ were plated per $35-\mathrm{mm}$ dish. After the 2 -h adherence period, the cells were $80 \%$ confluent and numbered $\sim 4 \times 10^{5}$ \% dish. These cells were $>99 \%$ macrophages as judged by nonspecific esterase (positive for macrophages) (23) and alkaline phosphatase

Table I. Synthesis of Complement Proteins in Lung Cells*

\begin{tabular}{|c|c|c|c|c|c|c|c|c|}
\hline & $n$ & & \% Purity & $\mathrm{C} 2$ & FB & $\mathrm{C4}$ & $\mathbf{C 3}$ & C5 \\
\hline & & & & \multicolumn{5}{|c|}{ cpm in specific protein $\times 10^{6} / \mathrm{cpm}$ in total protein } \\
\hline \multicolumn{9}{|l|}{ Rat } \\
\hline Alveolar type II & 6 & & $94 \pm 2$ & 16 & 25 & 6 & 52 & 8 \\
\hline Bronchoalveolar macrophages & 4 & , & $>99$ & 631 & 775 & - & 1 & - \\
\hline \multicolumn{9}{|l|}{ Human } \\
\hline Alveolar type II & 3 & & $89 \pm 4$ & 10 & 27 & 12 & 30 & 3 \\
\hline Bronchoalveolar macrophages & 4 & & $>99$ & 40 & 2 & - & 1 & - \\
\hline
\end{tabular}

* Results presented as means of results from the individual experiments. Labeled proteins were immunoprecipitated, separated by SDS-PAGE, and identified with fluorography. Slices containing the specific proteins were removed from the gel, digested, and counted after addition of scintillation fluid (radioactivity in slices without specific proteins were subtracted as background). Before immunoprecipitation, an aliquot of the sample was removed for determination of the radioactivity incorporated into TCA-precipitable protein. 
staining (positive for type II cells and negative for macrophages) (19) (Table I).

In the second method, cells that were adherent on IgG-coated bacteriologic plastic culture dishes after the 1-h adherence step for the type II cell isolation were washed and cultured in medium containing $10 \%$ FCS for two more hours. These cells were $95 \pm 2 \%$ macrophages, with the remaining cells being type II cells (Table II). The proportions of interstitial and bronchoalveolar macrophages were not determined.

Human pulmonary macrophages. Macrophages were obtained by two separate methods. Alveolar macrophages were obtained from smokers without active lung disease who were lavaged using standard techniques as controls for the Specialized Center of Research interstitial lung disease project at the National Jewish Center. Cells from the fifth or sixth lavage $(50 \mathrm{ml})$ were pelleted $\left(1,000 \mathrm{rpm}, 4^{\circ} \mathrm{C}\right)$, washed once in HBSS, and resuspended in DMEM without serum. The cells were adhered to tissue culture plastic dishes $\left(4 \times 10^{6}\right.$ cells in $1 \mathrm{ml}$ per $35-\mathrm{mm}$ dish) for $2 \mathrm{~h}$ before washing. The adherent cells were $>99 \%$ macrophages (Table I).

Pulmonary macrophages were also obtained as a byproduct of the type II cell preparation. Cells that were adherent on IgG-coated bacteriologic plastic culture dishes were washed and cultured in medium containing 10\% FCS for two more hours. These cells were $>99 \%$ macrophages (Table II). As with the rat macrophages obtained by this method, the proportions of interstitial and bronchoalveolar macrophages were not determined.

Minced lung tissue. Whole mouse and rat lungs were finely minced with a curved scissors, washed twice in HBSS, and divided into 50-mg portions, each of which was resuspended in $0.5-\mathrm{ml}$ portions of labeling media.

Table II. Contribution of Synthesis of Complement Proteins in Rat Type II and Pulmonary Macrophage Populations by Contaminating Cells*

\begin{tabular}{lcc}
\hline & Type II cells & Macrophages \\
\hline No. cells $\left(\times 10^{-5}\right)$ & 6.90 & 2.00 \\
No. contaminating cells $\left(\times 10^{-5}\right)^{\ddagger}$ & 0.45 & 0.10 \\
C2: total cpm & 2,251 & 1758 \\
cpm from contaminating cells & 177 & 54 \\
\% contaminating/total & 5 & 3 \\
FB: total cpm & 5,536 & 767 \\
cpm from contaminating cells & 85 & 171 \\
\% contaminating/total & 2 & 22 \\
C4: total cpm & 1,173 & 207 \\
cpm from contaminating cells & 105 & 26 \\
\% contaminating/total & 9 & 13 \\
C3: total cpm & 11,439 & 116 \\
cpm from contaminating cells & 14 & 229 \\
\% contaminating/total & 0.3 & 197 \\
C5: total cpm & 171 & 0 \\
cpm from contaminating cells & 0 & - \\
\% contaminating/total & 0 & - \\
\hline
\end{tabular}

* Results presented as means of duplicate samples from three separate experiments. Labeled proteins were processed as described in the legend to Table I. Counts per minute from contaminating cells were calculated by assuming that the entire amount of protein in a given cell mixture was synthesized by the major cell type; the number of counts per minute per cell were then multiplied by the number of those cells contaminating the other condition.

‡ Type II cells were contaminated primarily by macrophages, but also by a few other epithelial cells. Macrophages were contaminated by type II cells.

\section{Biosynthetic labeling and immunoprecipitation}

Immediately after the adherence periods, the cells were washed to remove conditioned medium and cultured for $2 \mathrm{~h}$ in $1.0 \mathrm{ml}$ methionine-free medium containing $500 \mu \mathrm{Ci}\left[{ }^{35} \mathrm{~S}\right]$ methionine $(24,25)$, except that the labeling medium contained protease inhibitors (10\% dialyzed heat-inactivated FCS, $1 \mathrm{mg} / \mathrm{ml}$ soybean trypsin inhibitor, and 100 $\mu \mathrm{g} / \mathrm{ml}$ pepstatin A) to prevent cleavage of the proteins after secretion. The extracellular medium was removed and the cells were washed twice in PBS (pH 7.4) and lysed by freeze-thaw in PBS containing protease inhibitors (10 $\mathrm{mM}$ EDTA and $2 \mathrm{mM}$ PMSF in addition to soybean trypsin inhibitor and pepstatin $A)$ and detergents $(0.5 \%$ Triton-X 100 and $0.25 \%$ sodium desoxy cholate). The intracellular lysates were processed for immunoprecipitation by clarification $(10,000 \mathrm{~g}$ for $15 \mathrm{~min}$ ) and preabsorption with the formalin-fixed $S$. aureus for 60 min at $4^{\circ} \mathrm{C}(25)$. Samples were immunoprecipitated by addition of excess monospecific antibody, incubation overnight at $4^{\circ} \mathrm{C}$, and addition of formalin-fixed $S$. aureus for $60 \mathrm{~min}$ at $4^{\circ} \mathrm{C}$. The Staph protein A-antibody-antigen complexes were washed and then dissociated by heating (boiling) in Laemmli sample buffer (pH 6.8) and the immunoprecipitates subjected to SDS-PAGE. The resulting gels were fixed, impregnated with $\mathrm{En}^{3} \mathrm{Hance}$, dried, and exposed at $-70^{\circ} \mathrm{C}$ to Kodak XAR-5 film. Samples were sequentially immunoprecipitated for the various proteins by preclearing with additional formalin-fixed $S$. aureus and then reimmunoprecipitated for the different antigens using the appropriate monospecific antibody. $\mathrm{C} 5$ was always the first antigen precipitated to avoid possible interference of residual C3-anti-C3 complexes with the $\mathrm{C} 5$ signal. Incorporation of $\left[{ }^{35} \mathrm{~S}\right]$ methionine into individual immunoprecipitated proteins was determined in gel slices after digestion with $15 \%$ hydrogen peroxide for $16 \mathrm{~h}$ and addition of ScintiVerse II (Fisher Scientific Co., Fair Lawn, NJ) $(24,25)$; the radioactivity in the gel slices was adjusted for the amount of total protein synthesized under the specific conditions, as determined by precipitation of aliquots of the lysates with $10 \%$ TCA (25). Preliminary experiments demonstrated that incorporation of $\left[{ }^{35} \mathrm{~S}\right]$ methionine into both total protein and specific complement proteins was dependent upon concentration of radiolabeled amino acid from 100 to $900 \mu \mathrm{Ci} / \mathrm{ml}$ and was linear with time of culture up to $2 \mathrm{~h}$.

\section{RNA analysis}

Total cellular RNA was prepared from frozen, pulverized organs or from washed tissue culture cells by cesium chloride gradient ultracentrifugation after lysis in $4 \mathrm{M}$ guanidinium thiocyanate (26). Poly $\mathrm{A}+$ RNA was purified from $100 \mu \mathrm{g}$ total cellular RNA using oligo-(dT)cellulose (27) and subjected to Northern analysis using mouse C5 cDNA (28) radiolabeled with ${ }^{32} \mathrm{P}$ by nick-translation.

\section{Results}

Synthesis of complement proteins in mouse and rat lung tissue. Minced lung tissue from normal mice synthesized and secreted C5. The intracellular proC5 was a single chain molecular mass of $\sim 180 \mathrm{kD}$ and the extracellular material was a two-chain molecule with an alpha chain of $117 \mathrm{kD}$ and a beta chain of 84 $\mathrm{kD}$ (Fig. 1). Lung tissue from C5-deficient mice had a protein $(\sim 187 \mathrm{kD})$ in the cell lysate at $60 \mathrm{~min}$, but no protein was visible in the extracellular media even at $24 \mathrm{~h}$. (The smaller molecular weight material present in the cell lysates and extracellular media after $24 \mathrm{~h}$ adsorbed nonspecifically to the Staph A [Fig. 1].) Lung tissue from the normal and C5-deficient mice synthesized and secreted equal amounts of C3 (data not shown).

Minced lung tissue from rats synthesized and secreted $\mathrm{C} 2$, factor B, C4, C3, and C5 (data for minced lung not shown; proteins from the whole lung were identical to those from rat type II cells shown in Fig. 2). The size and subunit composition of the $\mathrm{C} 2, \mathrm{C} 4$, factor $\mathrm{B}$, and $\mathrm{C} 3$ were identical to the 


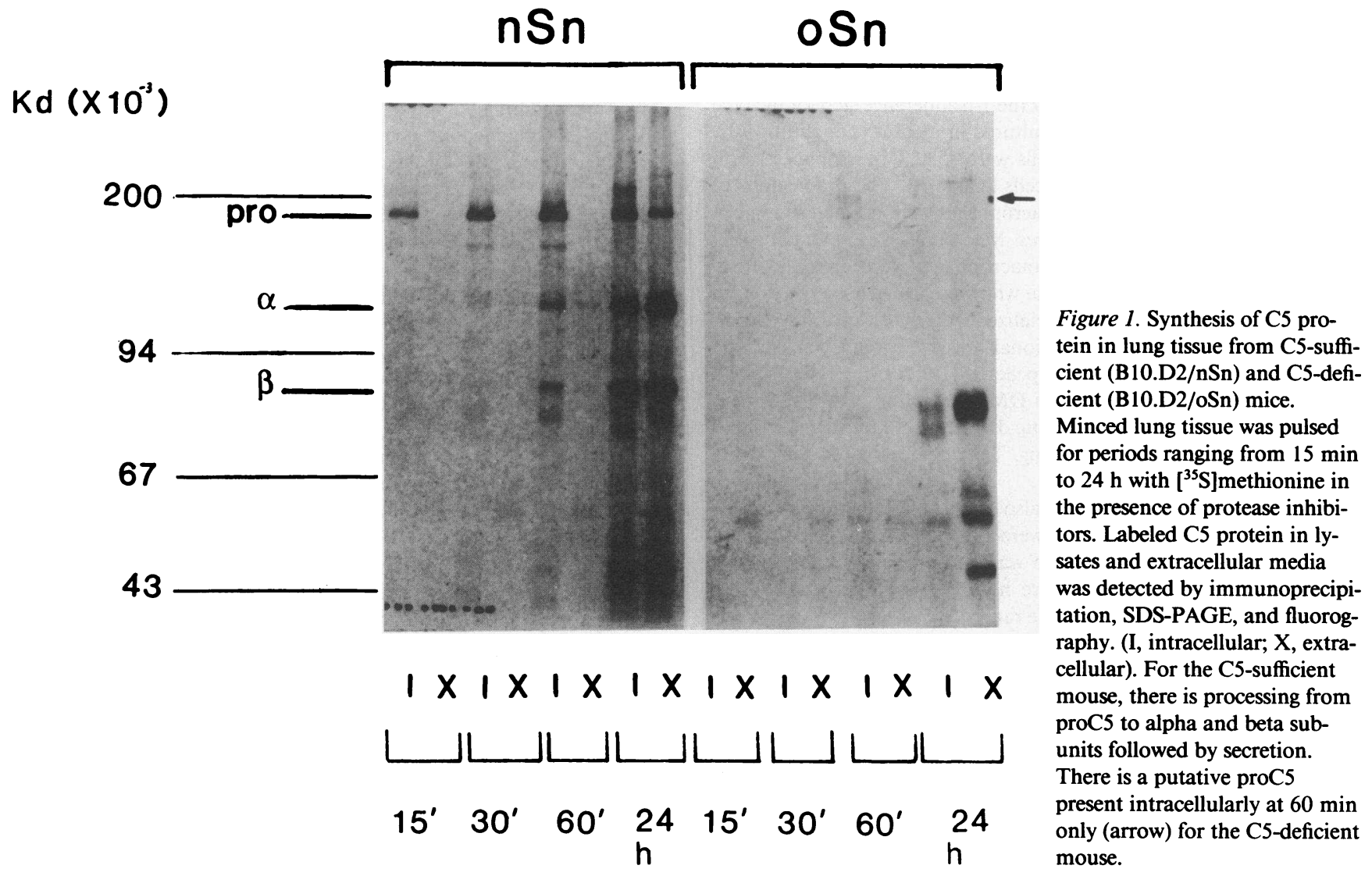

proteins precipitated from rat serum. The $\mathrm{C} 5$ had a molecular mass of $200 \mathrm{kD}$, slightly larger than the serum molecule, which is $\sim 180 \mathrm{kD}$. In addition, the $\mathrm{C5}$ protein secreted by the cells did not reduce into the alpha and beta chains characteristic of C5 from mouse, rat, and human sera and the C5 secreted from the mouse lung cells (Fig. 1). Minced whole lungs from rats in both specific pathogen-free and open colonies synthesized this single chain extracellular C5 molecule. Rat lung tissue contained C5 mRNA with the same molecular mass as the C5 mRNA in rat liver and in mouse liver and lung (Fig. 3). For both the mouse and rat, the amount of C5 mRNA in the lung was much less than in the liver.

Synthesis of complement proteins in specific rat lung cells. Because procedures for the isolation of type II cells from mice are not available, synthesis of complement proteins in specific lung cells was studied only in rats and humans. The complement proteins synthesized in rat type II cells are shown in Fig. 2. These cells synthesized C2, factor B, and C5 in each of 10 separate experiments, $\mathrm{C} 4$ in 8 of 10 experiments, and $\mathrm{C} 3$ in 9 of 10 . The $\mathrm{C} 5$ synthesized and secreted by the purified type II cells was identical to the material from the minced lung tissue. In addition, the type II cells contained C5 mRNA (data not shown). Analysis of radioactivity in specific gel slices indicated that factor B and C3 were the most prevalent proteins synthesized (Table I).

Because the rat type II cell cultures contained 4-8\% pulmonary macrophages, experiments were designed to test the possibility that these contaminating macrophages were responsible for the complement synthesis in the type II cell cultures.
Initial adherence of the macrophages to IgG-coated dishes and subsequent adherence of the type II cells to tissue culture plastic yielded parallel cultures of purified type II cells (94\% type II cells, $6 \%$ macrophages) and purified pulmonary macrophages (95\% macrophages, $5 \%$ type II cells) from the same animals. In each of three separate experiments, the type II cells and macrophages were pulsed with a single batch of $\left[{ }^{35} \mathrm{~S}\right]$ methionine containing medium, and production of specific proteins was quantitated. The results of the three experiments are shown in Table II. For the IgG-adherent pulmonary macrophages, synthesis of $\mathrm{C} 2$ and factor $\mathrm{B}$ was detected in each of the three experiments, $\mathrm{C} 4$ and $\mathrm{C} 3$ in only one of the three, and $\mathrm{C5}$ in none of the experiments. The type II cells synthesized all five complement proteins in each experiment. The possibility that the synthesis of these proteins was due to the contaminating pulmonary macrophages is analyzed in Table II. All five complement proteins detected in the type II cell cultures were synthesized by the type II cells, with only small contributions by the contaminating pulmonary macrophages. The $\mathrm{C} 2$, factor $\mathrm{B}$, and $\mathrm{C} 4$ detected in the pulmonary macrophage cultures were synthesized by the macrophages, but the $\mathrm{C} 3$ was probably synthesized by the type II cells contaminating the macrophage cultures. In addition to the decreased capacity of the macrophages to produce complement proteins, the pulmonary macrophages were not as metabolically active as the type II cells. Incorporation of $\left[{ }^{35} \mathrm{~S}\right]$ methionine into TCA-precipitable protein in the macrophages was $58 \mathrm{cpm} / \mathrm{cell}$ (range 44-72 for the three experiments) compared with $221 \mathrm{cpm} /$ cell for the type II cells (range 100-394). 


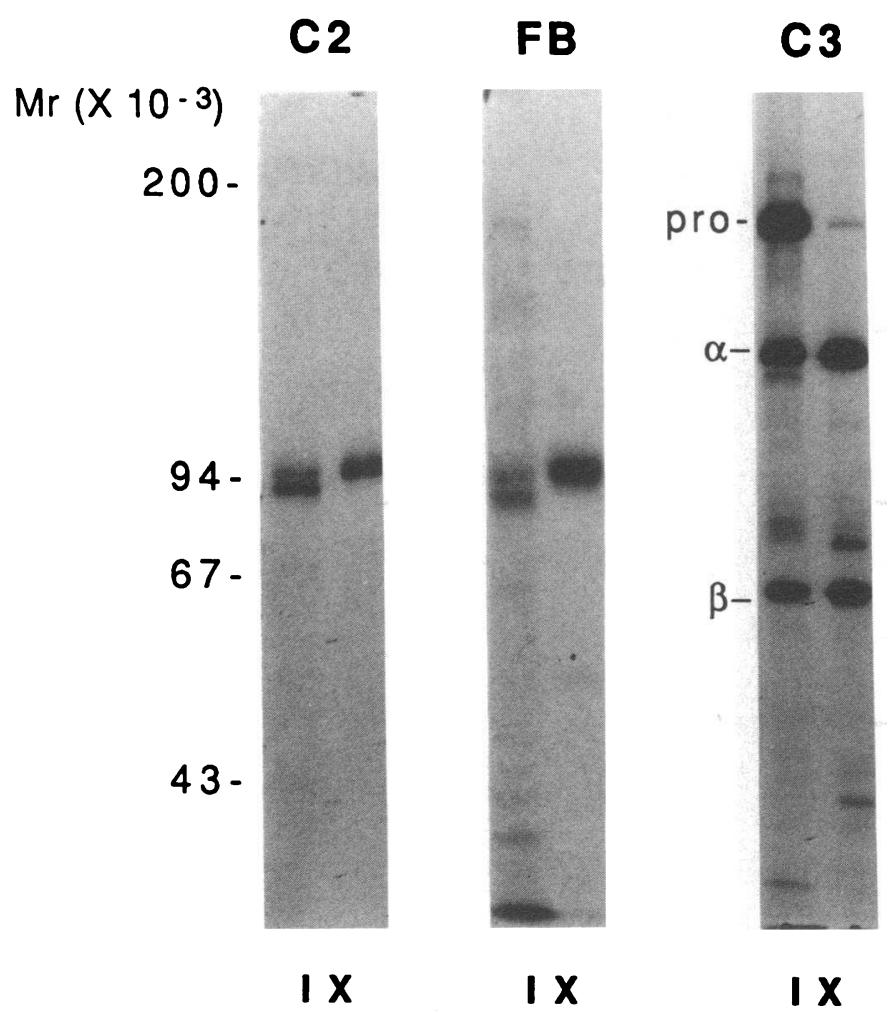

Figure 2. Synthesis of C2, factor B, C3, C5, and C4 in rat alveolar type II epithelial cells. Approximately $10^{6}$ type II cells were pulsed for $2 \mathrm{~h}$ with $\left[{ }^{35} \mathrm{~S}\right]$ methionine in the presence of protease inhibitors. The labeled complement proteins were sequentially immunoprecipitated with monospecific antibodies to the relevant proteins and detected by SDS-PAGE and fluorography. $\mathrm{C} 2$ and factor B demonstrated the smaller intracellular forms $(\sim 99$ and $\sim 98 \mathrm{kD}$, respectively) that were glycosylated intracellularly before secretion as the native forms ( $\sim 103$ and $\sim 106 \mathrm{kD}$, respectively); not shown in this

Rat bronchoalveolar macrophages synthesized much more C2 and factor B than the type II cells (Table I). Synthesis of C3 was detected in only one of the four experiments and synthesis

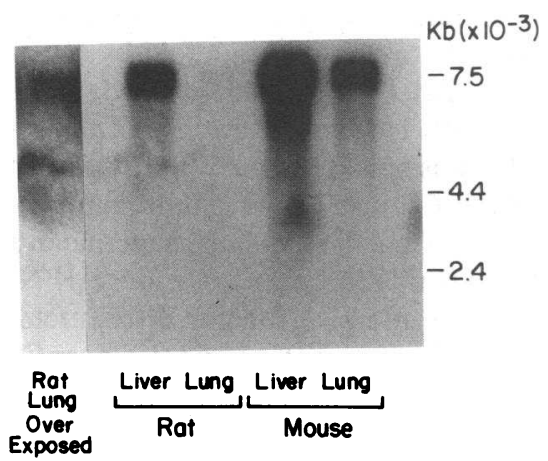

Figure 3. Analysis of C5 mRNA in lung tissue from a normal, C5sufficient mouse and a specific-pathogen free rat. Poly A+ RNA was extracted using oligo (dT)-cellulose from equal amounts of total cellular RNA (100 $\mu \mathrm{g})$ from liver and lungs of the two animals and subjected to Northern analysis using a ${ }^{32} \mathrm{P}$-nick translated mouse C5 cDNA. The hybridized Northern blot exposed to x-ray film for $18 \mathrm{~h}$ demonstrated a single species of C5 mRNA $(\sim 6.0 \mathrm{kD})$ in all four tissues, although the signal for the rat lung was faint. The signal for the $\mathrm{C} 5 \mathrm{mRNA}$ in rat lung after $5 \mathrm{~d}$ exposure is shown in the insert.

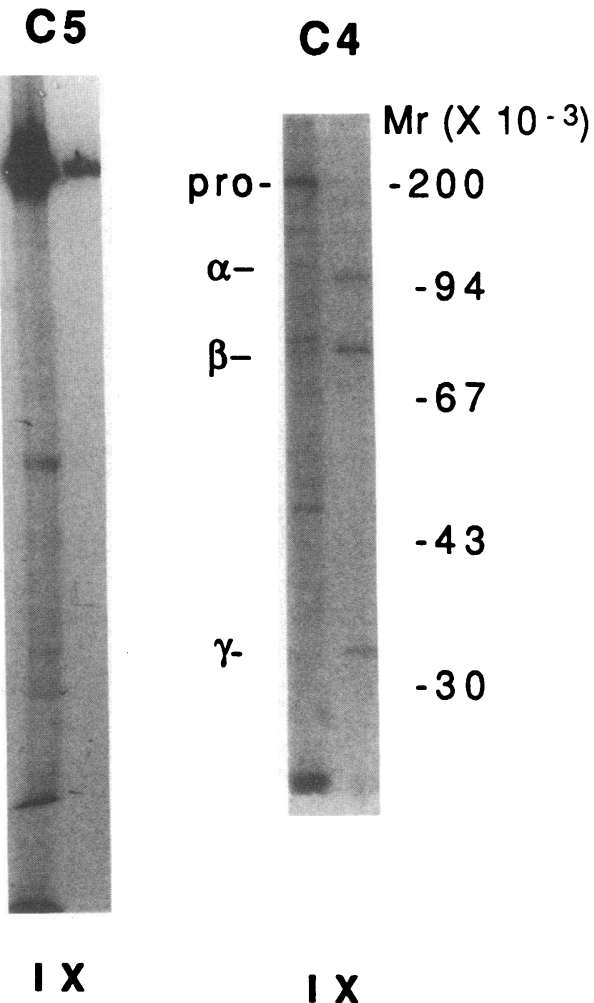

figure are the two cell-associated forms of $\mathrm{C} 2(\sim 97$ and $\sim 78 \mathrm{kD})$ that were seen in most experiments. $\mathrm{C} 3$ was synthesized as a single chain precursor $(\sim 180 \mathrm{kD})$ and cleaved into alpha $(\sim 120 \mathrm{kD})$ and beta $(\sim 74 \mathrm{kD})$ chains intracellularly before secretion. $\mathrm{C} 5$ synthesized in these cells $(\sim 205 \mathrm{kD})$ was slightly larger than serum C5 $(\sim 180 \mathrm{kD})$, and was not processed either before or after secretion. C4 was synthesized as a single chain precursor $(\sim 195 \mathrm{kD})$ and secreted as the typical three-chain molecule (alpha $\sim 109 \mathrm{kD}$, beta $\sim 70 \mathrm{kD}$, gamma $\sim 32 \mathrm{kD}$ ).

of C4 and C5 was not detected in any of the experiments. The overall metabolic activity of the bronchoalveolar macrophages was similar to the activity of the pulmonary macrophages obtained from adherence of cells in elastase-digested lung to IgG-coated plates (incorporation of $\left[{ }^{35} \mathrm{~S}\right]$ methionine into TCA-precipitable protein was $40 \mathrm{cpm} /$ cell, range 13-74 in four experiments).

Synthesis of complement proteins in human lung cells. Type II cells were obtained from three patients undergoing lobectomy for carcinoma, and purified by adherence to bovine endothelial cell extracellular matrix (21). Similar to the results with the rat type II cells, the human cells synthesized C2, C4, factor B, C3, and C5 proteins (Fig. 4). These proteins had the same size and subunit composition as the proteins in human serum. Specifically, the C5 had a molecular mass of $180 \mathrm{kD}$ intracellularly and 126 and $78 \mathrm{kD}$ for the extracellular alpha and beta chains, respectively. These results were similar to those of the alpha and beta chains of $\mathrm{C} 5$ purified from serum (120 and $73 \mathrm{kD}$ ) and C5 synthesized by HepG 2 cells (125 and $75 \mathrm{kD})$. Factor $B$ and $C 3$ were the most prevalent of the five complement proteins synthesized in the human type II cells (Table I).

In one experiment, type II cells and pulmonary macrophages obtained from a single donor were studied to determine if the contaminating macrophages were responsible for the 


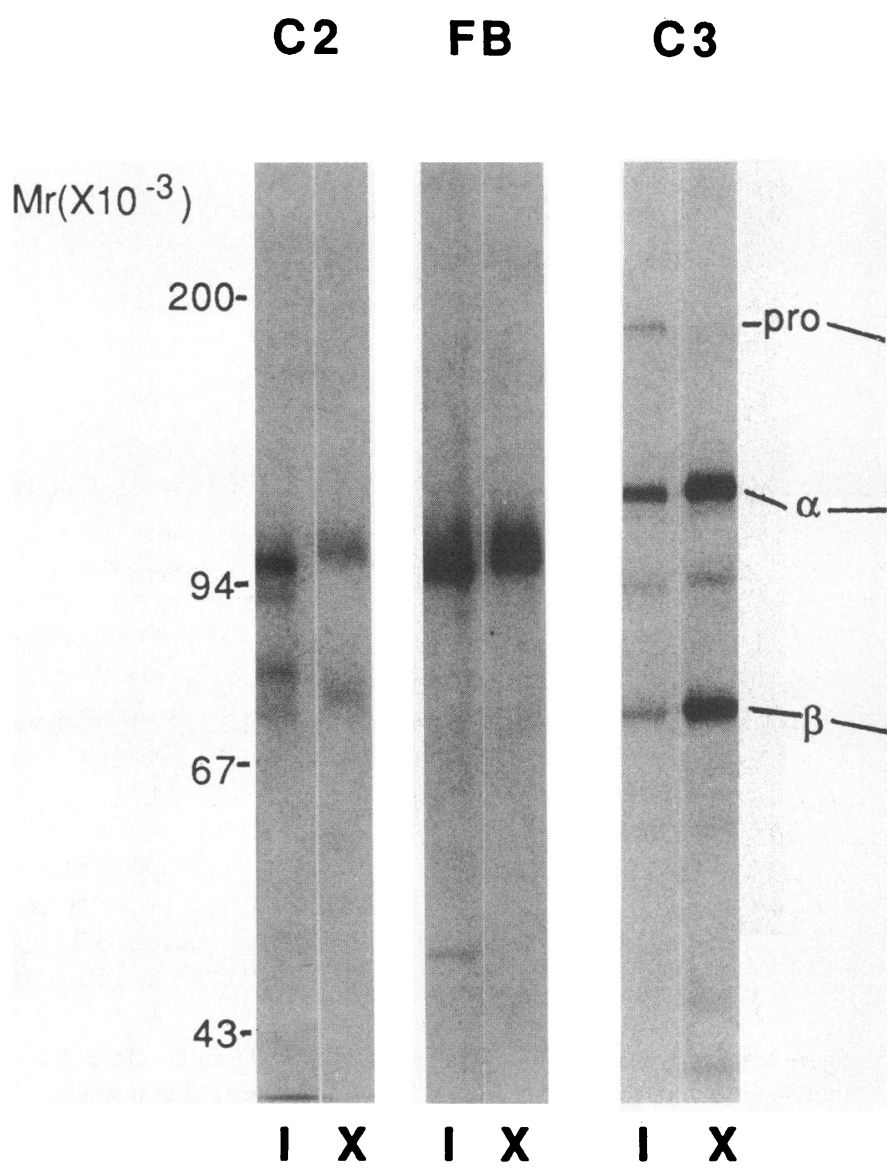

Figure 4. Synthesis of C2, factor B, C3, C5, and C4 in human alveolar type II epithelial cells. Approximately $10^{6}$ type II cells were pulsed, labeled, and processed as described in the legend for Fig. 2. C2 and factor B demonstrated the smaller intracellular forms $(\sim 103$ and $\sim 99 \mathrm{kD}$, respectively) and the larger, glycosylated extracellular forms ( $\sim 112$ and $\sim 105 \mathrm{kD}$, respectively). Two cell-associated forms of $\mathrm{C} 2(\sim 97$ and $\sim 78 \mathrm{kD})$ were also present. The $\mathrm{C} 3$ and $\mathrm{C} 5$

complement synthesis in the type II cell cultures, similar to the approach used with the rat cells. Initial adherence of pulmonary macrophages to IgG-coated dishes and subsequent adherence of the type II cells to the extracellular matrix yielded parallel cultures of purified type II cells ( $85 \%$ type II cells, $15 \%$ macrophages) and purified pulmonary macrophages ( $>99 \%$ macrophages without contaminating type II cells). Each type of culture was studied in triplicate. Pulmonary macrophages synthesized $\mathrm{C} 2$ and factor $\mathrm{B}$, but not $\mathrm{C} 4, \mathrm{C} 3$, or $\mathrm{C} 5$. Using an analysis similar to the one using rat type II cells shown in Table II, the results with the human cells indicated that the type II cells synthesized all five complement proteins with a minimal amount of synthesis being contributed by the contaminating pulmonary macrophages. Specifically, macrophages could have contributed only $25 \%$ of the C2 and $0.1 \%$ of the factor B synthesized in the type II cell cultures.

Bronchoalveolar macrophages from smokers without lung disease synthesized $C 2$ and factor $B$ in each of the four separate experiments (Table I). C3 was synthesized in only one of the four experiments, and synthesis of $\mathrm{C} 4$ or $\mathrm{C} 5$ was not detected in any experiment. The human bronchoalveolar cells synthesized more C2 than the type II cells, but not more factor B.
C5

C4

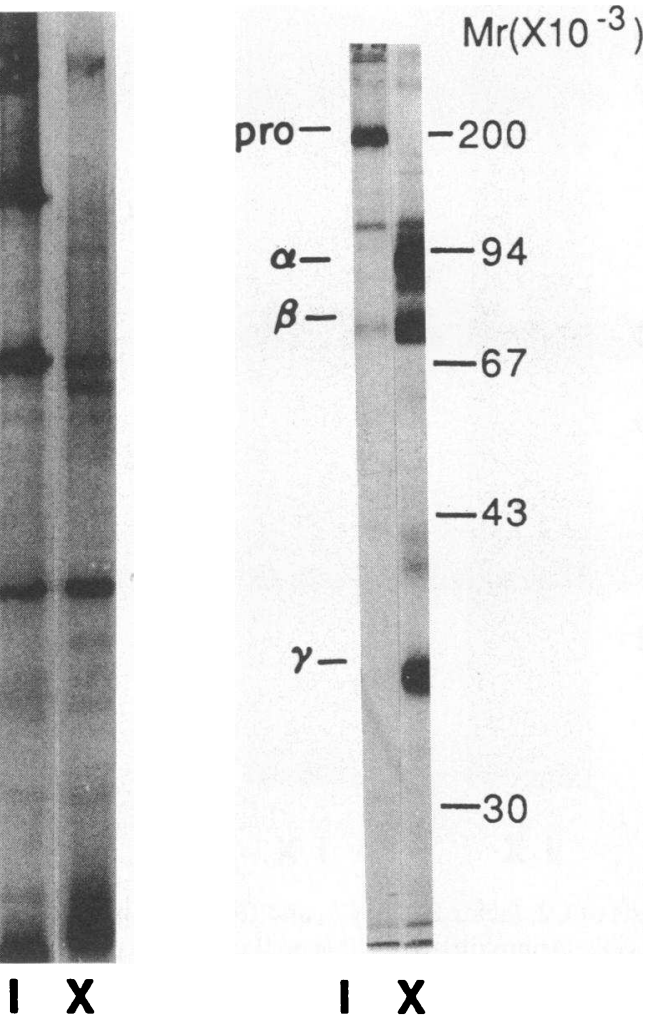

were similar: pro forms $\sim 178$, alpha $\sim 126$, and beta $\sim 78 \mathrm{kD}$. Both were processed intracellularly to alpha and beta chains before secretion. The monospecific antisera to $\mathrm{C} 3$ and $\mathrm{C} 5$ did not crossreact, in that human $\mathrm{C} 5$ purified from serum blocked immunoprecipitation of C5 but not C3. C4 was synthesized as a single chain precursor $(\sim 195 \mathrm{kD})$ and secreted as the typical three-chain molecule (alpha $\sim 93$, beta $\sim 75$, gamma $\sim 35 \mathrm{kD}$ ).

Regulation of synthesis of complement proteins in type II cells. In three separate experiments, synthesis of Factor B in rat type II cells was stimulated an average of eightfold by supernatants from Con A-stimulated rat spleen cells. Maximal stimulation was achieved with 1:10 concentrations of the supernatant. Synthesis of $\mathrm{C} 2$ was also stimulated (fourfold), but increases in synthesis of $\mathrm{C} 3, \mathrm{C} 4$, and $\mathrm{C} 5$ were minimal (twofold or less). The effect of the Con A-stimulated supernatants was reproduced by $100 \mathrm{U} / \mathrm{ml}$ recombinant mouse IFNgamma, with stimulation of synthesis of factor B (eightfold) and $\mathrm{C} 2$ (threefold) without a significant effect on $\mathrm{C} 3, \mathrm{C} 4$, or C5 synthesis. $100 \mathrm{ng} / \mathrm{ml} \mathrm{LPS} \mathrm{stimulated} \mathrm{synthesis} \mathrm{of} \mathrm{factor} \mathrm{B} \mathrm{(10-}$ fold) and C3 (fourfold), but did not affect synthesis of C2, C4, or C5.

\section{Discussion}

In this report we present evidence that type II alveolar epithelial cells synthesize and secrete proteins of both the classical (C2, C4) and alternative (factor B) complement activation pathways, and $\mathrm{C} 3$ and $\mathrm{C} 5$, precursors of phlogistic molecules. The type II cells synthesized much more $\mathrm{C} 3$ but less $\mathrm{C} 2$ and 
factor B than pulmonary macrophages obtained by adherence after digestion of lung tissue or bronchoalveolar lavage. Compared with synthesis of complement proteins in the human monocyte, the type II cells synthesized comparable amounts of factor B and C3, but somewhat less C2 (24).

Several lines of evidence suggest that type II alveolar epithelial cells synthesize and secrete C5. Purified human type II cells synthesized and secreted a C5 protein with the same size and subunit composition as the $\mathrm{C} 5$ in human serum. Although the purified human type II cell preparations contained up to $15 \%$ pulmonary macrophages, the cultures of macrophages alone did not synthesize C5. Rat type II cell preparations also synthesized a C5 protein. Similar to the results with the human cells, the small number of contaminating pulmonary macrophages (5-8\%) did not account for the C5 synthesis in the type II cell preparations. The $\mathrm{C} 5$ molecule secreted by the rat type II cell cultures had only a single chain with a molecular mass of $\sim 200 \mathrm{kD}$, different from the C5 protein in rat serum. Similar differences between serum $\mathrm{C} 5$ and the $\mathrm{C} 5$ synthesized by cells in vitro have also been observed for studies using mouse peritoneal macrophages (29). The identity of the molecule synthesized by the rat type II cells as $\mathrm{C} 5$ was supported by its immunoprecipitation with four separate anti-C5 antisera, including an anti-mouse $\mathrm{C5}$ produced in $\mathrm{C5}$-deficient mice, and the presence of C5 mRNA in both whole rat lung tissue and in rat type II cells. Finally, minced lung tissue from normal, but not C5-deficient, mice synthesized and secreted a C5 molecule characteristic of serum $\mathrm{C} 5$. The $\mathrm{C} 5$ protein synthesized but not processed and secreted by the deficient cells has also been noted by Ooi and Colten (30).

Preliminary studies have indicated that the capacity of rat type II cells to synthesize complement proteins is increased by lymphokines and LPS. These data suggest that interactions of mediators produced in the lung during inflammation with the complement producing cells in the lung may provide a mechanism for regulation of production of complement proteins in the lung independent from regulation in the liver. This hypothesis is supported by the findings of Cole and co-workers, demonstrating differences in rates of synthesis of complement proteins in bronchoalveolar macrophages as compared with rates in monocytes and macrophages derived from other tissue sites (31), and by studies by Cole et al. (32) indicating that changes in the biosynthesis of complement in bronchoalveolar macrophages were not predicted by levels of serum complement.

Because of the importance of $\mathrm{C5}$ in the mediation of inflammation, several authors have studied its site of synthesis. The hepatocyte is a site of C5 synthesis in the mouse, guinea pig, and human (9). Identification of other cell types responsible for $\mathrm{C} 5$ synthesis in these species has been controversial. Studies with fetal tissues demonstrated $\mathrm{C} 5$ production by a wide variety of tissues, suggesting that $\mathrm{C} 5$ is produced by a widely distributed cell type (33). Peritoneal macrophages synthesized C5 in the mouse (29), but evidence for active synthesis of $\mathrm{C} 5$ in guinea pig peritoneal macrophages could not be demonstrated (34). In the human, Whaley reported that peripheral blood monocytes incorporated radiolabeled amino acids into a protein that precipitated with antiserum to C5 in Ouchterlony analysis (35), but other investigators could not detect $C 5$ protein with the expected size and subunit composition (36) or C5 mRNA (Strunk, R. C., and F. S. Cole, unpublished observations) in these cells. Several studies have suggested that cells in the lung synthesize $\mathrm{C} 5$. Kolb et al. noted that $\mathrm{C} 5 /$ albumin ratios in lavage fluids were 3.5 -fold higher than the corresponding ratios in matched serum samples, suggesting that the protein was synthesized, at least in part, by cells in the lung (37). Kreutzer and co-workers (14) have reported production of hemolytically active C5 in cultures of fetal lung cells and suggested that the type II epithelial cell may be a site of synthesis of C5. Previous studies of complement synthesis in cells isolated from the lung have been confined largely to bronchoalveolar lavage macrophages, which synthesize $\mathrm{C} 2$ and $\mathrm{C} 4$ in guinea pigs (12) and C2, factor B, and C3 in humans (11). Although several authors have suggested that the alveolar macrophage may be a site of synthesis of $\mathrm{C} 5$, synthesis of this protein could not be demonstrated in human alveolar macrophages from either normal subjects or patients with a variety of pulmonary diseases (11).

In our experiments, bronchoalveolar lavage macrophages from four adult smokers without lung disease synthesized large amounts of $\mathrm{C} 2$, less factor $\mathrm{B}$, and in one experiment, $\mathrm{C} 3$, similar to the findings of Cole et al. (11). The data from the experiments with rat bronchoalveolar lavage macrophages were similar to those with human cells, except that the rat cells synthesized much more $\mathrm{C} 2$ and factor B. Although these differences may be species specific, they may also be due to the environment of the cells and differences in the overall capacity of the cells to function: the human cells contained large numbers of carbon particles related to the smoking habits of the donors, and the rat cells did not contain these foreign particles.

Alveolar type II epithelial cells play an essential physiologic role in the alveolus by synthesizing and secreting surface-active material, by restoring the alveolar epithelium after damage to type I cells, and by transepithelial solute transport (38). Although type II cells secrete a variety of proteins, the function of many of these proteins are not known. The localization of synthesis of several complement proteins to the type II cell extends the spectrum of the functions of these cells. Since human tissue is relatively unavailable and its exposure to inflammatory stimuli (both type and duration) is usually poorly defined, use of rat lung cells could provide a model for more detailed study of the regulation of complement proteins during pulmonary inflammation.

\section{Acknowledgments}

The authors thank Dr. Patsy Giclas for performing the hemolytic complement assays, Ms. Susan Jennings for expert technical assistance in isolation of rat and human type II cells, and Ms. Jane Watkins for preparation of the manuscript.

This work was supported in part by grants from the National Institutes of Health (DK-26605, HL-27353, AI-25011, HL-37591, and HL-33139) and from Great-West Life Assurance Company. Dr. Strunk received the Allergic Diseases Academic Award K07-AI00543.

\section{References}

1. Reid, K. B. M., and R. R. Porter. 1981. The proteolytic activation systems of complement. Annu. Rev. Biochem. 50:433-464.

2. Fernandez, H. N., P. M. Henson, A. Otani, and T. E. Hugli. 1978. Chemotactic response to human $\mathrm{C} 3 \mathrm{a}$ and $\mathrm{C} 5 \mathrm{a}$ anaphylatoxins. I. Evaluation of $\mathrm{C} 3 \mathrm{a}$ and $\mathrm{C} 5 \mathrm{a}$ leukotaxis in vitro and under stimulated in vivo conditions. J. Immunol. 120:109-115.

3. Henson, P. M., K. McCarthy, G. L. Larsen, R. O. Webster, P. C. 
Giclas, R. B. Dreisin, T. E. King, and J. O. Shaw. 1979. Complement fragments, alveolar macrophages, and alveolitis. Am. J. Pathol. 97:93110.

4. Larsen, G. L., B. C. Mitchell, T. B. Harper, and P. M. Henson. 1982. The pulmonary response of $C 5$ sufficient and deficient mice to Pseudomonas aeruginosa. Am. Rev. Respir. Dis. 126:306-311.

5. Larsen, G. L., B. C. Mitchell, and P. M. Henson. 1981. The pulmonary response of C5 sufficient and deficient mice to immune complexes. Am. Rev. Respir. Dis. 123:434-439.

6. Parrish, D. A., B. C. Mitchell, P. M. Henson, and G. L. Larsen. 1984. Pulmonary response of fifth component of complement-sufficient and -deficient mice to hyperoxia. J. Clin. Invest. 74:956-965.

7. Craddock, P. R., J. Fehr, K. L. Brigham, R. S. Kronenberg, and H. S. Jacob. 1977. Complement and leukocyte-mediated pulmonary dysfunction hemodialysis. N. Engl. J. Med. 269:769-774.

8. Wheat, W. H., R. Wetsel, A. Falus, B. J. Tack, and R. C. Strunk. 1987. The fifth component of complement (C5) in the mouse: analysis of the molecular basis for deficiency. J. Exp. Med. 165:1442-1447.

9. Cole, F. S., and H. R. Colten. Complement Biosynthesis. 1988. The Complemental System. K. Rother and G. O. Till, editors. Springer-Verlag, Berlin, West Germany. 44-70.

10. Al-Adnani, M. S., and J. O'D. McGee. 1976. Clq production and secretion by fibroblasts. Nature (Lond.). 263:145.

11. Cole, F. S., W. J. Matthews, T. H. Rossing, D. J. Gash, N. A. Lichtenberg, and J. E. Pennington. 1983. Complement biosynthesis by human bronchoalveolar macrophages. Clin. Immunol. Immunopathol. 27:153-159.

12. Pennington, J. E., W. J. Matthews, J. T. Marino, and H. R. Colten. 1979. Cyclophosphamide and cortisone acetate inhibit complement biosynthesis by guinea pig bronchoalveolar macrophages. $J$. Immunol. 123:1318-1321.

13. Ackerman, S. K., P. S. Friend, J. R. Hoidal, and S. D. Douglas. 1978. Production of $\mathrm{C} 2$ by human alveolar macrophages. Immunology. 35:369-372.

14. Kreutzer, D. L., J. Verani, W. Douglas, and M. E. Blazka. 1980. Elaboration of complement components by primary cultures and continuous lines of human type II pneumocytes. Am. Rev. Respir. Dis. 121:78. (Abstr.)

15. Cinader, B., S. Dubiski, and A. C. Wardlaw. 1964. Distribution, inheritance and properties of an antigen, MUB1, and its relation to hemolytic complement. J. Exp. Med. 120:897-924.

16. Dobbs, L. G., E. F. Geppert, M. C. Williams, R. D. Greenleaf, and R. J. Mason. 1980. Metabolic properties and ultrastructure of alveolar type II cells isolated with elastase. Biochim. Biophys. Acta. 618:510-523.

17. Kikkawa, Y., and K. Yoneda. 1974. The type II epithelial cell of the lung. I. Method of isolation. Lab. Invest. 125:76-84.

18. Mason, R. J., S. R. Walker, B. A. Shields, J. E. Henson, and M. C. Williams. 1985. Identification of rat alveolar type II epithelial cells with a tannic acid and polychrome stain. Am. Rev. Respir. Dis. 131:786-788.

19. Edelson, J. D., J. M. Shannon, and R. J. Mason. 1986. Alkaline phosphatase: an enzyme histochemical stain to differentiate alveolar type II cells from macrophages. Am. Rev. Respir. Dis. 133:A292. (Abstr.)

20. Dobbs, L. G., R. Gonzalez, and M. W. Williams. 1986. An improved method for isolating type II cells in high yield and purity. Am. Rev. Respir. Dis. 134:141-145.
21. Robinson, P. C., D. R. Voelker, and R. J. Mason. 1984. Isolation and culture of human alveolar type II epithelial cells. Characterization of their phospholipid secretion. Am. Rev. Respir. Dis. 130:1156-1160.

22. Gospodarowicz, D. C. 1980. Extracellular matrix and control of proliferation of vascular endothelial cells. J. Clin. Invest. 65:13511364.

23. Koski, I. R., D. G. Poplack, and R. M. Blaese. 1976. A nonspecific esterase stain for the identification of monocytes and macrophages. In In Vitro Methods in Cell-Mediated and Tumor Immunity. B. R. Bloom and J. R. David, editors. Academic Press, Inc. New York. 359-362.

24. Strunk, R. C., A. S. Whitehead, and F. S. Cole. 1985. Pretranslational regulation of the synthesis of the third component of complement in human mononuclear phagocytes by the lipid A portion of lipopolysaccharide. J. Clin. Invest. 76:985-990.

25. Strunk, R. C., F. S. Cole, D. H. Perlmutter, and H. R. Colten. 1985. Gamma-interferon increases expression of class III complement genes $\mathrm{C} 2$ and factor $\mathrm{B}$ in human monocytes and in murine fibroblasts transfected with human $\mathrm{C} 2$ and factor B genes. J. Biol. Chem. 260:15280-15285.

26. Chirgwin, J. M., A. E. Przygyla, R. J. MacDonald, and W. J. Rutter. 1979. Isolation of biologically active ribonucleic acid from sources enriched in ribonuclease. Biochemistry. 18:5294-5298.

27. Aviv, H., and P. Leder. 1972. Purification of biologically active globin messenger RNA by chromatography on oligothymidylic acidcellulose. Proc. Natl. Acad. Sci. USA. 69:1408-1412.

28. Wetsel, R. A., R. T. Ogata, and B. F. Tack. 1987. Primary structure of the fifth component of murine complement. Biochemistry. 26:737-743.

29. Ooi, Y. M., and H. R. Colten. 1979. Biosynthesis and post-synthetic modification of a precursor (pro-C5) of the fifth component of mouse complement (C5). J. Immunol. 123:2494-2498.

30. Ooi, Y. M., and H. R. Colten. 1980. Genetic defect in secretion of complement C5 in mice. Nature (Lond.). 282:207.

31. Cole, F. S., E. E. Schneeberger, N. A. Lichtenberg, and H. R. Colten. 1982. Complement biosynthesis in human breast milk macrophages and blood monocytes. Immunology. 46:429-441.

32. Cole, F. S., W. J. Matthews, J. T. Marino, D. J. Gash, and H. R. Colten. 1980. Control of complement synthesis and secretion in bronchoalveolar and peritoneal macrophages. J. Immunol. 125:1120-1124.

33. Colten, H. R. 1972. Ontogeny of the human complement system. In vitro biosynthesis of individual complement components by fetal tissues. J. Clin. Invest. 51:725-730.

34. Colten, H. R. 1976. Biosynthesis of complement. Adv. Immunol. 22:67-118.

35. Whaley, K. 1980. Biosynthesis of the complement components and the regulatory proteins of the alternative complement pathway by human peripheral blood monocytes. J. Exp. Med. 151:501-516.

36. Beatty, D. W., A. E. Davis, F. S. Cole, L. P. Einstein, and H. R. Colten. 1981. Biosynthesis of complement by human monocytes. Clin. Immunol. Immunopathol. 18:334-343.

37. Kolb, W. P., L. M. Kolb, R. A. Wetsel, W. R. Rogers, and J. O. Shaw. 1981. Quantitation and stability of the fifth component of complement (C5) in bronchoalveolar lavage fluids obtained from nonhuman primates. Am. Rev. Respir. Dis. 123:226-231.

38. Mason, R. J., and M. C. Williams. 1977. Alveolar type II cell. Defender of the alveolus. Am. Rev. Respir. Dis. 115:81-92. 